\title{
Experiencing the Good Life as We Age: Heeding Aristotle's Advice
}

ISSN: 2578-0093

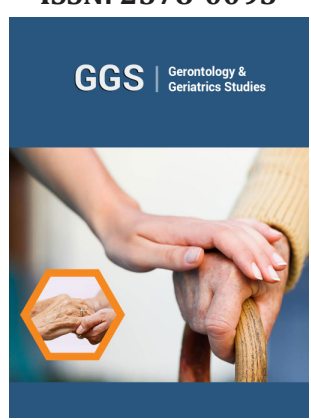

*Corresponding author: John Dattilo, Penn State University, U.S.A.

Submission: 眥 September 13, 2019

Published: 泚September 18, 2019

Volume 5 - Issue 1

How to cite this article: Dattilo J, Frias FJL and Chen CT (2019) Experiencing the Good Life as We Age: Heeding Aristotle's Advice. Gerontol \& Geriatric stud.5(2): 488-489. GGS.000606.2019.

DOI: 10.31031/GGS.2019.05.000606

Copyright@ John Dattilo, This article is distributed under the terms of the Creative Commons Attribution 4.0 International License, which permits unrestricted use and redistribution provided that the original author and source are credited.

\section{Dattilo J*, Frias FJL and Chen CT}

Department of Recreation, Park, and Tourism Management, Penn State University, U.S.A

\section{Abstract}

Exploring the good life using writings of Aristotle helps us to determine how we can live our lives so that we age healthfully. Aristotle et al. [1] recommends that we engage is virtuous acts so that we avoid excess and deficiency as we strive to achieve the mean. Virtuous actions associated with the mean are helpful to consider when we attempt to pursue the good life. In this article, we argue that being virtuous, such as practicing forgiveness, acting courageously, and being friendly assist us in experiencing the good life as we age.

\section{Experiencing the Good Life as We Age: Heeding Aristotle's Advice}

Based on writings of Aristotle and others, we use the phrase the good life to identify the valuable role virtues play in achieving happiness. "The good life is shorthand for a wide diversity of admirable ways of living, ways that embody the virtues and other values in myriad ways" [2]. Virtues are "dispositions to choose relative to a mean determined by reason, the kind of reason that a person of practical wisdom would employ" [1]. We become virtuous by developing good dispositions, or habits, that help us to know the right action and direct our desires to choose it. Aristotle argues that virtuous actions lead to the good life by allowing us to achieve intrinsically valuable goods connected to specific human experiences and activities.

Exploring the good life using writings of Aristotle helps us to determine how we can live our lives so that we age healthfully. Philosophical inquiry provided by Aristotle shifts our focus from external values to connections between internal and external values. This distinction is central to the good life, for what we consider as intrinsically good makes our lives worth living [3]. Aristotle et al. [1] distinguishes between what is good and what is instrumentally good to other ends, and he regards the good life as the only good that is purely intrinsically valuable because we do not pursue it for any other end. For instance, we acquire wealth to be able to afford goods and experiences that have monetary value. We pursue wealth not for its own sake, but for the sake of those goods and experiences. However, we do not regard the good life to other ends. Instead, everything we do is for the sake of the good life. As we age, we can learn about ways to orient our lives toward actions that are virtuous, such as emphasizing goodness, promoting happiness, and deemphasizing external values such as generating income, promoting physical attraction, and increasing popularity [4]. For example, Sheldon \& Kasser et al. [5] examined autonomy, goal motivation, and well-being and found older respondents report higher internal and lower external values than younger participants. Aristotle et al. [1] recommends that we engage is virtuous acts so that we avoid excess and deficiency as we strive to achieve the mean. Virtuous actions associated with the mean are helpful to consider when we attempt to pursue the good life. Aristotle identifies each virtue as a mean condition allowing a person to be virtuous while avoiding deficiency or excess. Chen \& Frias et al. [6] identified relevance of the following virtuous actions to promote health aging

a) practice forgiveness,

b) act courageously and

c) be friendly.

Harboring unspoken resentments resulting from negative encounters, including people making ageist comments, often leads to loneliness [7]. "Forgiveness is the internal act of relinquishing anger, resentment, and the desire to seek revenge against someone who has caused harm as well as the enhancement of positive emotions and thoughts towards the harm- 
doer" Bies \& Aquino et al. [8]. Aristotle claims that forgiveness is the mean condition between deficiency in sensitivity and anger. As we age, we can practice recognizing ageist or demeaning statements as cues for forgiveness.

Virtuous people distinguish right from wrong and find courage to engage in virtuous acts. Aristotle defines courage as the disposition to act appropriately in the mean condition of fear and confidence-a rationally determined mean between rashness as he states, "In the field of fear and confidence the mean is courage. The one who exceeds in confidence is called rash, and the one who shows an excess of fear and deficiency of confidence is called cowardly." Aristotle et al. [1] courage is valuable in dealing with issues related to aging including end-of-life issues such as life-sustaining treatment or advance care planning since these issues can be stressful [9]. In these instances, courage is useful to overcome fears and redirect our energies to find enjoyment, so the good life is experienced.

"Friendliness is a social predisposition that indicates a willingness to communicate with another person without first suspicion or doubt" Kapur \& Chong [10]. For Aristotle, friendship is a relationship that embodies, promotes, and fosters virtue. Friendliness involves engaging in virtuous activities with people of good character. Friends value each other for their virtues and appreciate each other for who they are. Being friendly helps to demonstrate our virtue as we learn from each other about ways to become more virtuous. One way to create opportunities to demonstrate friendliness is to help people engage in meaningful volunteer activities. Assisting others, supporting neighbors, and serving our community or place of residence, positively influences our mental and physical health as we age [11].

As we age, we encounter various positive experiences as well as challenges. Though challenges prevent some of us at sometimes from experiencing the good life, it is valuable for us to engage in virtuous actions directed at achieving the mean to increase chances we experience the good life. Being virtuous, such as practicing forgiveness, acting courageously, and being friendly assist us in experiencing the good life as we age. For instance, forgiving others who act in ways that reflect negative stereotypes may help us cope with stress associated with ageism. Courageous acts tend to empower us to handle adverse situations, act in ways promoting social connections, and engage in behaviors conducive to the good life. Being friendly may be a way to contribute to positive feelings and decrease loneliness. Overall, we believe that Aristotle provides us with guidance as we age to experience the good life.

\section{References}

1. Aristotle (2004) The Nicomachean ethics. In: Thomson JAK (Ed.), NY: Penguin, New York.

2. Martin MW (2012) Happiness and the good life. NY: Oxford University Press, New York.

3. Hurka T (2015) The best things in life: A guide to what really matters. NY: Oxford University, New York.

4. Sheldon KM, Kasser T (2001) Getting older, getting better? Personal strivings and psychological maturity across the life span. Dev Psychol 37(4): 491-501.

5. Sheldon KM, Hourser ML, Kasser T (2006) Does autonomy increase with age? Comparing the goal motivations of college students and their parents. Journal of Research in Personality 40(2): 168-178.

6. Chen S, Dattilo J, Frias FJL (2018) Pursuing the good life to facilitate healthy aging: Advice from sages and social psychologists. Therapeutic Recreation Journal 52(2): 170-189.

7. Greenstein M, Holland J (2015) Lighter as we go: Virtues, character strengths, and aging. NY: Oxford Press, New York.

8. Bies RJ, Barclay LJ, Tripp TM, Aquino K (2016) A systems perspective on forgiveness in organizations. The Academy of Management Annals 10(1): 245-318.

9. Gebara J, Tashjian H (2006) End-of-life practices at a Lebanese hospital: courage or knowledge? J Transcult Nurs 17(4): 381-388.

10. Kapur B, Chong KC (2002) Altruistic reveries: Perspectives from the humanities and social sciences. Hardback, Dordrecht, Netherlands.

11. Theurer K, Wister A (2010) Altruistic behaviour and social capital as predictors of well-being among older Canadians. Ageing \& Society 30(1): 157-181. 